\title{
IS U.S. PUBLIC SECTOR LABOR RELATIONS IN THE MIDST OF A TRANSFORMATION?
}

\author{
HARRY C. KATZ*
}

\begin{abstract}
In this article the author assesses whether a fundamental transformation is underway in public sector (state and local government) labor relations in the United States by revisiting the arguments made by the author and Kochan and McKersie (1986) regarding the transformation of labor relations in the private sector. The author argues that the economic pressures that led to a transformation of private sector labor relations starting in the 1980s have not played a comparable role in recent developments in the public sector because of the political nature of labor relations in that sector. Other insights are drawn from a comparison of recent developments with events that occurred during the mid-1970s, an earlier taxpayer revolt era. The author concludes that a fundamental transformation in public sector labor relations has not occurred, attributable to some degree to the limited decline in public employee union membership and the fact that a majority of the public has favorable attitudes toward public sector employees and union collective bargaining rights. Factors that might lead to such a transformation in the future are highlighted.
\end{abstract}

$\mathrm{O}$ ver the last several years a number of state and local government political leaders and commentators have called for sharp limits on the collective bargaining rights of public employees and the unions that represent those employees. These calls have been bolstered by claims that public employees are overpaid and that their overly generous pension benefits are unsustainable. In a number of states new laws to eliminate or limit public sector collective bargaining and union rights have been enacted or proposed (Dannin 2012; Hurd and Lee forthcoming). These claims and the legislative actions that have followed have raised concerns about the future of public sector labor relations.

In this article I assess whether a fundamental transformation is underway in public sector labor relations in the United States. I do so by revisiting the arguments made by the author and Kochan and McKersie (1986) regarding the transformation of labor relations in the private sector. At the core of this assessment is an evaluation of whether the power held by public sector

\footnotetext{
*Harry C. Katz is the Kenneth F. Kahn Dean and the Jack Sheinkman Professor of Collective Bargaining at the School of Industrial \& Labor Relations, Cornell University. The author thanks participants in the Collective Bargaining Workshop at the ILR School, Jeff Keefe, Tom Kochan, and three anonymous referees for helpful suggestions, and Shane Seppinni for able research assistance.
}

ILRReview, 66 (5), October 2013. ( by Cornell University. Print 0019-7939/Online 2162-271X/00/6605\$05.00 
unions has significantly eroded. The basic sources of bargaining power in the public sector are clarified and contrasted with the sources of bargaining power in the private sector. Focus in this article is placed on state and local government labor-management relations because the critics of public employee collective bargaining focus on that sector and because the overwhelming majority of employees who work in public employment do so for state and local governments. ${ }^{1}$

\section{The Private Sector Transformation Argument}

Thomas Kochan, Robert McKersie, and I argued that a transformation started in private sector labor relations in the United States in the early 1980s (Kochan, Katz, and McKersie 1986). We observed significant changes in the process and outcomes of labor relations, making use of a three-tier framework that distinguishes a strategic, functional, and workplace level of collective bargaining. The key driver of this transformation was a shift in bargaining power in management's favor, induced by increased international competition, a growing and highly competitive domestic nonunion sector, a severe economic recession in the early 1980s, and deregulation in a number of key industries. These underlying economic pressures enabled management to act at the strategic level to drive change by making use of shifts in investment (abroad or domestically to nonunion alternatives) and other changes in corporate strategy and structure to weaken union influence. Other changes included bargaining outcomes involving pay cuts or freezes and other major "concessions" at the functional (middle) tier of labor relations and a reorganization of work practices at the workplace level often involving reductions in job classifications, more contingent compensation, team systems of work, and more direct communication between workers and managers, which often bypassed traditional channels of worker and union leader influence.

A key bargaining process change induced by the reduction in labor's bargaining power was more decentralized bargaining through either formal shifts (the abandonment or marked decline in multi-company bargaining) or informal shifts (the erosion of pattern bargaining or the movement of issues from company-level resolution to plant work group-level resolution).

When analyzing bargaining process changes and the workplace implications of the transformation underway in private sector labor relations, Kochan, McKersie, and I (KKM) made use of the concept of labor relations "patterns" as an analytic tool (Fox 1974: 297-313; Katz, Kochan, and Colvin 2008: 108-12). The primary claim in this concept is that work practices cluster into defined patterns (or clusters) rather than being more randomly distributed, and that much of the tension involved in everyday labor

\footnotetext{
${ }^{1}$ As of November 2012, 16.3 million $(76 \%)$ of the 21.4 million employees who worked in the public sector in the United States worked for state or local governments (http://bls.gov/web/empsit/ceseebla $. h \mathrm{tm})$.
} 
relations is associated with the difficulties of shifting related practices in a coherent manner that yields higher performance (Katz, Kochan, and Colvin 2008: Chapter 5). KKM contrasted the so-called New Deal pattern of work practices and procedures with a more participatory pattern. The former involved job control oriented practices such as numerous job classifications and formulaic wage determination ("wage rules") while the latter made use of team systems of work organization and contingent compensation (Katz 1985; Katz and Darbishire 2000). KKM also observed that a sophisticated nonunion pattern had emerged as a serious challenge to traditional union work practices along with pressures that arose from a more traditional low wage pattern, which also operated on a nonunion basis.

Arguments that expressed the transformation debate in terms of whether a shift was occurring away from traditional adversarial labor relations to more cooperative labor relations trivialized the debate and ignored changes in the structure and patterns of labor relations. More serious criticisms of the transformation thesis are provided in Chelius and Dworkin (1990) and Dunlop (1988 and 1993).

\section{The Roots of Transformation-Changes in Bargaining Power}

Implicit in this transformation argument are assumptions about the sources of bargaining power. For the purposes of this article, it is helpful to clarify those sources of power as they become relevant when developments in the public and private sectors are compared.

Bargaining power comprises total and relative power. Total power is the amount of resources available to be divided between labor and management at any point in time in a given bargaining relationship. Total power in the private sector equates to the level of profits, which is influenced by both macro- and microeconomic factors (Katz, Kochan, and Colvin 2008: 78-85). The strategic determinants of relative bargaining power in the private sector are strike leverage and the elasticity of demand for labor. Strike leverage matters because intelligent bargainers on either side would not agree to a negotiated settlement that differs much from the outcome that could be achieved with a strike (or lock-out). In effect, the expected strike outcome serves as the threat point in negotiations in terms of whether a strike actually occurs (Hicks 1932). Ceteris paribus, labor has more bargaining power in a given negotiation if it is more willing or able to stay out on strike and vice versa. The industrial relations literature has long recognized that workto-rule, mass absenteeism, sabotage, or similar in-plant strategies can also exert strike-like pressure, and such tactics frequently arise in everyday negotiations as a source of leverage.

The competitive pressures cited above exert their influence in part by lowering total power or by giving management greater strike leverage; for example, the international operations of multinational firms can enhance management's ability to continue to operate during a strike or to absorb the financial losses associated with a strike action. The availability of domestic 
nonunion operations as a source of strike replacement production similarly can greatly enhance management's strike leverage.

The elasticity of demand for labor matters because workers and the union care about the level of employment and not just about compensation (Marshall 1920). Workers and the union have more bargaining power, ceterus paribus, when the trade-off between wages and employment is less severe (i.e., less elastic) because in that situation labor is more willing to make use of any strike leverage it has and to press for an improvement in compensation (or some other contract term). Here again one can use these concepts to trace the role played by various economic factors that were leading to the private sector transformation mentioned above. For example, international competition reduced total power and increased management's relative bargaining power by making product demand more elastic and by increasing the availability of substitute labor, thereby also making the demand for labor more elastic.

In the United States, political factors do not generally directly influence bargaining power in the private sector given the limited amount of direct governmental intervention in the decisions made by private sector firms. Government actions indirectly influence the total bargaining power of labor and management by affecting the degree of competition and macroeconomic demand and through their influence on strike leverage or the elasticity of demand for labor. For example, trade or other regulatory policies influence relative bargaining power by shifting the elasticity of demand for labor or by altering either side's ability or willingness to strike. The influence of government will be of particular relevance as we now compare the origins of bargaining power in the private and public sectors given the prominent role that politics plays as a direct influence on employment terms and conditions in that sector.

\section{Bargaining Power in the Public Sector}

Total power in the public sector is determined by the revenue (i.e., tax revenues, revenue sharing, and fees for services) available to be distributed between labor and management in a manner analogous to the role played by profits in a private sector negotiation. Also, as in the private sector, both strike leverage and the elasticity of demand for labor are critical determinants of relative bargaining power in the public sector, even though the strength of their influence is altered by the particular circumstances common in public sector labor relations in the United States. For one thing, that public sector employees do not commonly have the legal right to strike reduces, but does not eliminate, the leverage public employees gain from a strike action or a strike threat. As the 2012 Chicago teachers' strike illustrates, some public employees do have the legal right to strike. Even more important, the absence of the legal right to strike does not prevent strikes from occurring or strike threats from being meaningful. A telling illustration of an illegal public sector strike is when transit workers in New York City 
went on strike in 2005, even in the face of severe penalties imposed by the New York State "Taylor Law" on strikers and the striking union. ${ }^{2}$ Perhaps even more important than strike actions or threats are the strike-like actions such as work slowdowns or "blue flus" that can, and do, take place in the public sector.

Also relevant, twenty-two state laws provide binding interest arbitration as an impasse resolution procedure for at least some state and/or local government employees (Katz, Kochan, and Colvin 2008: 362). Most often these interest arbitration statutes cover police and firefighters but not all state or municipal employees in a given state. When interest arbitration is the binding impasse resolution procedure, the potential arbitration outcome serves as the threat point in negotiations and thereby influences negotiated outcomes whether interest arbitration is actually called into play to settle a given negotiation (Farber and Katz 1979).

The elasticity of demand for labor also matters as a key determinant of relative bargaining power in the public sector as workers and unions in the public sector, just like their private sector counterparts, are likely to consider the trade-off between improvements in contract terms and continued employment as they assess whether to make use of their ability to press for improvements in compensation. Here again the particulars of the labor relations situation and the environment matter. Given the local and service nature of public sector service provision, alternative sources of production are typically much more limited in the public sector than they are in the private sector, and hence, the demand for labor tends to be more inelastic in the public sector than it is in the private sector. In particular, international sources of supply are more limited for public services although the availability of private domestic sources via privatization can make the elasticity of demand significantly more elastic and to some extent counterbalance the lessened role for international sourcing.

How the public sector differs most from the private sector in regard to the determinants of bargaining power is that politics exerts direct influences on the determination of employment conditions in the public sector. This influence occurs because expenditures, employment levels, compensation, and other contract terms are often decided by elected officials or by voters. Labor relations is said to be multi-lateral in the public sector because of the diffusion of managerial authority, a factor that expands the variety of political factors and political channels that influence public sector labor relations (McLennan and Moskow 1968: 34-41; Kochan 1974). As a result, in the public sector both labor and management have a strong incentive to spend significant time and resources trying to influence public opinion or public officials either through lobbying or through electoral politics. Consequently, for example, public employee unions in certain situations can go around

${ }^{2} \mathrm{~A}$ key aspect of the Taylor Law is the law's imposition of a two-day penalty for each day an employee is on strike. 
recalcitrant elected officials and appeal to other elected officials in an attempt to influence public decisions.

In the debates surrounding whether public employees should be granted the right to form unions and whether those unions should be restricted, which occurred in the late 1970s, the importance of politics in public sector labor relations came to the fore. For example, Harry Wellington and Ralph Winter $(1969,1971)$ argued for strict limits on collective bargaining rights and union rights on the grounds that public employees and their unions exert undue political influence. Wellington and Winter also claimed that public employees would have complex (and in their view harmful) interests given their dual roles as citizens and employees when they live in the jurisdiction where they work. These public employee/citizens could influence public expenditure and employment terms as citizen voters and not just as employees or union members/activists.

At the same time, recognition of the important role played by politics in public sector decision making does not necessarily lead to the conclusion that collective bargaining or union rights should be significantly limited in the public sector. John Burton and Charles Krider (1970), for example, in a rebuttal of Wellington and Winter, pointed out that the bargaining power that labor or management actually has in a given public sector setting is an empirical question. In particular, management may find ways to exert significant political power, potentially by aligning with community or business groups or other political actors so as to limit public employee or union power and gains (Katz 1979).

Keep in mind that political influence on bargaining power in the public sector also might operate through indirect channels; namely, by affecting either strike leverage or the elasticity of demand for labor. What is clear is that to assess bargaining power in the public sector, it is essential to evaluate the political power of labor and management and that this political power in the public sector, in contrast to the private sector, in the United States operates through direct as well as indirect channels.

\section{Recent Events-Evidence of Transformation?}

As mentioned above, the core KKM transformation argument was that heightened international competition, growing domestic competition, deregulation, and the emergence of a sophisticated nonunion workplace pattern pressured private sector unions into concessions and other related bargaining outcome and process changes.

Not yet clear is whether the basic economic competitive pressures that led to this transformation of labor relations in the private sector have played a comparable role in the public sector in recent years. The influence of each of these economic factors in the public sector seems much more modest than what has transpired in the private sector. For example, given the local and service nature of public good provision, the role of international sourcing or the influence of multinational corporations has been limited. 
And while privatization has made alternative providers and other alternative nonunion provision more feasible, privatization has expanded only gradually since the early 1990 s.

Furthermore, growing empirical evidence suggests that privatization, when it has occurred, brings along significant, often hidden, costs and often has limited effectiveness (Sclar 2001; Hefetz and Warner 2011; Hefetz, Warner, and Vigoda-Gadot forthcoming). This evidence shows there has been no dramatic increase in the scale or success of privatization in recent years, especially not on the scale that could lead to transformative change. Nor are there regulatory changes operating in the public sector that compare to the deregulation that took place in the trucking, airlines, and telecommunications industries in the U.S. private sector.

\section{The Absence of a Shift to More Decentralized Bargaining Structures in the Public Sector}

Another key aspect of private sector transformation that does not appear in the public sector is the shift to more decentralized collective bargaining structures. The public sector in the United States, on the contrary, has long been characterized by extremely decentralized bargaining, especially that involving elementary and secondary education in which key allocation decisions are most commonly made at the local school district level (Anderson 1972). For other public services, in many cities and states highly fragmented collective bargaining occurs. New York City, for example, negotiates more than 100 separate collective bargaining agreements, and any form of coalition bargaining among these units historically has been rare (Lewin and McCormick 1981). Although pattern bargaining influences contract outcomes in New York City and some other public jurisdictions, no evidence of a significant shift to more decentralized bargaining in these or other public jurisdictions has been observed.

If anything, a drift to more centralized collective bargaining due to centralization in the control of the public financing of municipal expenditures has occurred. This move is particularly true in elementary and secondary education for which state courts have ruled that the local financing of public schools has worked to disadvantage school children in poor communities. These court rulings have led some states to shift to greater state involvement and control of local school funding (Katz, Kochan, and Colvin 2008: 357).

Another example of increased centralization in public sector collective bargaining is that a number of states have taken action to address health care costs at the state level and in doing so have either taken this issue off the table of local bargaining units or constrained possible options. In Massachusetts, for example, the state passed a law mandating that local communities either join the state-wide health care plan (thereby getting significant savings from the bargaining power the state enjoys in dealing with Blue Cross and other carriers) or agree to equivalent savings in their local plans. 
Private sector labor relations transformation also has involved an increase in the occurrence of a participatory union pattern of labor relations (Kochan, Katz, and McKersie 1986; Katz and Darbishire 2000; and Katz, Kochan, and Colvin 2008: 109). While the actual spread and success of this participatory pattern in the private sector remains in dispute, in part attributable to the absence of any sort of national survey of workplace practices, little evidence of a similar spread in the public sector can be found beyond a few showcase examples of participatory labor relations in local school districts and some experimentation with more contingent compensation and team systems of work in a few municipal or state jurisdictions (U.S. Department of Labor 1996; Lewin, Kochan, and Keefe 2012; Rubinstein and McCarthy 2012). The growth of either sophisticated nonunion or participatory union labor relations patterns in the public sector clearly has been modest.

\section{Developments in the Elementary and Secondary School Sector}

Elementary and secondary school teachers and expenditures represent a sizeable fraction of public employment and public sector budgets. ${ }^{3}$ Consequently, developments in elementary and secondary education exert a critical influence on the course of public sector labor-management relations. Public schools are heavily unionized while the growing private school sector, which includes charter schools, is largely nonunion. So, the extent of further privatization of elementary and secondary education may emerge as a pressure for broad change in public sector labor relations.

At the same time, several factors are likely to limit the growth of school privatization. For one thing, unionized teachers in a number of school districts have exhibited a willingness to agree to significant pay and work rule concessions as part of negotiated changes in collective bargaining agreements (Lewin, Keefe, and Kochan 2012). In addition, unionized teachers in many school districts have accepted teacher evaluation systems and other performance management changes (Rubinstein and McCarthy 2012). As a result, whether de-unionization or even more modest weakening of union influence is a necessary ingredient to progressive school reform is not clear. Furthermore, a growing body of research calls into question the claims that charter and other private schools have inherent student achievement or other performance advantages (Ravitch 2010; Loeb 2011).

\section{The Political Nature of Public Sector Labor Relations}

The critical drivers of developments in Wisconsin and other jurisdictions that call into question the future strength of public employees and their unions are political in nature. Public employee and public employee union

\footnotetext{
${ }^{3}$ As of November 2012, 7.8 million "education" workers within a total of 14.1 million local government workers were employed, which equals $56 \%$ of all local government employment (http://bls.gov/web /empsit/ceseebla.htm).
} 
rights have been challenged by the political actions of figures such as governors Chris Christie in New Jersey or Scott Walker in Wisconsin. If a fundamental transformation were to emerge in public sector labor relations it would most likely come as a result of the reduced willingness of the public to pay for public expenditures or public employee contract gains. Taxpayer actions can have the most significant effect on public sector labor relations through the reductions in total power that occur by means of reductions in available revenues. Secondary effects on the relative power of public employee unions could occur through the increased willingness of the public to withstand strikes or the efforts of public officials to explore alternative sources of supply for public services. All of these changes in bargaining power involve channels through which political factors influence public sector labor relations. The point is that any significant transformation of public sector labor relations would likely be driven by shifts in the political power of public employees and their unions.

\section{Comparisons with the Mid-1970s Taxpayer Revolt}

Given the critical role that politics can play in public sector labor relations, insights into the future of public sector labor relations can be gleaned by re-examining an earlier era when taxpayer attitudes seemingly turned against public employees and their unions. During spring 1975, a "taxpayer

revolt" was propelled by the default crisis that emerged when New York City was unable to cover its operating expenses and had to rely on support from New York State. New York City administrators also reset compensation terms in a number of New York City employee labor agreements, which included wage freezes and pension reductions (Weitzman 1979). Concern that similar budget problems were occurring in other jurisdictions spread to other cities and states in the late 1970s, and this in turn contributed to legislative changes such as the passage of Proposition 13 in California, which sharply limited property tax revenues. From 1975 to 1979, eight states, in addition to California, passed some sort of tax or public expenditure limitation (Government Employee Relations Report 1979). These ballot measures exercised large effects because they led to significant reductions in tax revenues and correspondingly, reduced the total power held by labor and management in those jurisdictions.

In San Francisco, a traditional "labor town," in 1975 and 1976 public employees faced an energized Board of Supervisors, including future senator Diane Feinstein, and an activated business community who pointed to New York City's default crisis as they pressed for labor concessions from San Francisco's employees. Steep concessions did indeed follow for a number of San Francisco's employees, and changes in the city's pension plans covering police and firefighters occurred only after voters approved ballot measures that specifically altered pay and pension setting procedures or levels (Katz 1979).

A number of parallels can be noted in the taxpayer concerns that surfaced in the mid-1970s and those that have arisen recently in various states. 
In New York City in 1975, anger against public employee unions was fueled by claims that the city's default was in large part due to the increased costs of pensions received by city employees. Similarly, in San Francisco in 1976, citizens and the business community were particularly agitated by the alleged large pension benefits received by city police and firefighters as well as questions about whether, and for how long, the city could afford its pension obligations (Katz 1979). In recent years much attention has likewise been focused on the long-term costs of city and state public employee pensions. In addition, attention in the media has been drawn to the financial crises and potential bankruptcies facing the national governments of Greece and Spain due to alleged expensive public employee salaries and pensions.

At the same time, it is telling that in the mid-1970s while rollbacks in public employee compensation occurred in several municipalities and future public sector revenue growth was constrained in some states, as in California, through the passage of various tax-limiting propositions and laws, this taxpayer revolt did not last and did not lead to transformative changes in public sector labor relations. Rather, by the early 1980s, concerns about U.S. competitiveness (with Japan and Europe) drew attention to the importance of education and led to calls from the Carnegie Commission and others for increases in public school expenditures. These concerns, in turn, led to the stabilization of public school labor relations in many districts throughout the country. This stabilization helped to produce sizeable contract gains for teachers. One indicator is that teacher median pay grew relative to the median pay for private sector employees in the 1980s. Katz and Kochan (2004: 343) reported that average annual earnings of elementary and secondary school teachers relative to the average earnings of private sector production and nonsupervisory workers fell from 1.18 in 1975 to 1.09 in 1980 , but this ratio then rose to 1.20 in 1985 and 1.44 in $1990 .{ }^{4}$ Also noteworthy is that the pay and benefit concessions imposed on public employees in New York City and San Francisco (and elsewhere) were not accompanied by legislative changes that limited public employee union membership or collective bargaining rights.

Furthermore, the levels of union membership and coverage by collective bargaining did not fall after 1975. The percentage of all public sector employees who were union members in fact rose in the late 1970s: from 24.5 in 1974 to 25.4 in 1976 and to 35.9 by 1980 (http://www.unionstats.com/). Thus, the mid-1970s taxpayer revolt did not lead to declines in either public sector union membership or union coverage.

By the early 1990s the taxpayer revolt had effectively morphed into a campaign for greater privatization. This led to calls for a "reinventing of government" by then Vice President Al Gore and others, but as noted above, this

\footnotetext{
${ }^{4}$ The average earnings of municipal police and firefighters relative to production workers earnings showed a similar pattern (Katz and Kochan 2004: 342). Statistical analysis of earnings differentials by Bender and Heywood (2012: 148-49 and 157-60) also showed increases in state and local government employee earnings relative to private sector earnings in the 1980 s.
} 
did not lead to large increases in the share of public sector services that were actually provided through private sector service provision.

\section{Recent Public Attitudes toward Public Employees and Their Unions}

Evidence that public attitudes toward public employee and public sector union collective bargaining rights have fundamentally changed in recent years also is limited. A February 2011 New York Times/CBS News poll asked a sample of citizens the following questions. "As you may know, collective bargaining refers to negotiations between an employer and a labor union's members to determine the conditions of employment. Some states are trying to take away some of the collective bargaining rights of public employee unions. Do you favor or oppose taking away some of the collective bargaining rights of these unions? If Favor or Oppose; Do you favor or oppose that strongly or somewhat?" Only $18 \%$ of those polled favored strongly and $15 \%$ favored somewhat while 38\% opposed strongly and 22\% opposed somewhat (New York Times and CBS News Poll 2011). Another question in the same poll asked, "In order to reduce state budget deficits, do you favor cutting the pay or benefits of public employees?" Of those polled, $17 \%$ favored this strongly and $20 \%$ favored this somewhat while $29 \%$ strongly opposed and $27 \%$ somewhat opposed cutting pay or benefits of public employees to reduce state budget deficits.

When voters have been directly presented with laws that would explicitly limit collective bargaining and unionization in the public sector, they have not supported those measures in recent ballots. For example, in Ohio, in November 2011, residents (by a margin of $61.3 \%$ to $38.7 \%$ ) voted to repeal legislation that would have limited public employee collective bargaining rights in the state (http://ballotpedia.org/wiki/index.php/Ohio_Senate_Bill _5_Veto_Referendum,_Issue_2_\%282011\%29). More recently, in November 2012, voters in Idaho strongly (58\% of voters) rejected a proposition that would have limited teachers' rights to collectively bargain on wages and benefits (Linn 2012). Furthermore, while data from two Fields polls done in California in 2009 and 2011 revealed that the share of respondents who thought public employee pensions were too generous had risen, even in 2011, "more respondents thought pensions were about right or not generous enough than thought them too generous" (Mitchell 2012: 212). Also possible is that any taxpayer concerns about excessive public employee or union rights that now do exist will be allayed by the accumulating evidence that on average public employees are not paid more than their private sector counterparts, even when pension costs and other fringe benefits are accounted for (Lewin, Keefe, and Kochan 2012).

State or federal courts may well rule unconstitutional, or for other reasons sharply limit, new laws that constrain public employee and public sector union rights. For example, a Wisconsin state court in September 2012 voided most of that state's new law restricting the collective bargaining rights of public sector employees, ruling that the law unconstitutionally 
infringed on workers' rights to free speech, freedom of associations, and equal protection (Bologna 2012).

\section{Public Employee Union Membership Trends}

Clearly, public sector union power will be heavily influenced by the size and resources of those unions and not just by public attitudes. Hence, examining membership trends within public sector unions is of value. In 2012, the percentage of local and state government employees who were members of unions stood at, respectively, 41.7 and 31.3. In 2008 those percentages were 42.2 and 31.6..$^{5}$ Although the size of this decline in union membership across the country is not large, the declines occurring in states that had made significant changes to legislation regulating union membership and union bargaining rights have been much larger. For example, the number of government employees in Wisconsin belonging to a union dropped by 48,000 in 2012 , to 139,000 from $187,000 .{ }^{6}$ If the pace of this decline were to continue in Wisconsin and to spread to other states, then the likelihood of significant transformation in public sector labor relations would increase given that large union membership declines would inevitably lead to union power declines through one channel or another.

Union membership losses could reduce the direct power of public employee unions by reducing the number of unionized employees who through their voting behavior could influence public budget measures or the electoral fortunes of candidates based on those candidates' views toward public employee pay or public employee union rights. Less directly, reductions in union membership would reduce union dues and thereby the financial resources public employee unions would have access to with which to support political lobbying. Given the limited right to strike and the limited overall access to binding arbitration that exists in the public sector, it is less likely that future ballot measures will influence public employee union power through further limits on strikes or interest arbitration rights.

\section{The Probable Future of U.S. Public Sector Unionism and Labor Relations?}

History suggests that it is wise to be cautious when making predictions about union growth and the future of collective bargaining. For example, industrial relations scholars in the 1920s failed to anticipate the massive increase in worker militancy and union growth that occurred during the 1930s and 1940s in the United States. Another reminder of the difficulties of prediction

\footnotetext{
${ }^{5}$ The percentage of local and state government employees represented by unions (i.e., covered by collective bargaining agreements), respectively, stood at 46.1 and 35.1 in 2008 and had fallen to 45.2 and 34.9 in 2012 (http://www.bls.gov/schedule/archives/all_nr.htm).

${ }^{6}$ As Barry Hirsch kindly explained to the author, the sample sizes used to estimate the Wisconsin union membership figures are not large, yet Wisconsin data from other years suggest that the 2012 membership decline is not noise (http://Unionstats.com—Barry Hirsch and David Macpherson 2013).
} 
is provided by the inaccurate forecast of four of our field's leading scholars-Clark Kerr, John Dunlop, Frederick Harbison, and Charles Myers. In their magisterial book, Industrialism and Industrial Man, published in 1960, Kerr et al. wrote as if unions would become ever more prevalent and influential in the United States and around the globe. They failed to realize that by 1960, unions and collective bargaining (at least in the private sector) in the United States were already in the midst of what has turned out to be a prolonged and deep decline.

My review of recent developments in the public sector in the United States suggests that unions and collective bargaining in that sector, while facing severe pressures, is not yet transforming on a scale similar to what occurred in the private sector in the United States. The likelihood that economic pressures will induce fundamental change in the public sector is limited given that the various economic changes that propelled the transformation in private sector labor relations-international competition and a growing, more sophisticated nonunion sector-have not yet occurred and may never occur in the public sector given the inherent local and service nature of public service provision.

Nonetheless, my analysis has identified four primary factors that have the potential to produce the sort of pressures that could lead to future transformations.

1. Given the importance of public attitudes to both total and relative power in the public sector and the potential volatility of those attitudes, major shifts in the public's views regarding the legitimacy and appropriate role for unions and collective bargaining in the public sector could produce transformation. Above I reviewed the limited available evidence suggesting that public attitudes have not turned against public employee unions or collective bargaining. Yet, if those attitudes do sour, then greater change in public sector labor relations would likely ensue.

If the public were to greatly reduce the revenues accruing to state and local governments, by reducing the total power of labor and management, significant cutbacks in public employee pay could result. Or, urged on by the conservative PACs and other entities now participating actively in policy debates, another possibility would be that legislation eliminating public employee union rights could lead to widespread declines in public employee union membership, which could then greatly reduce public employee union power or more directly constrain public sector collective bargaining.

2. The revenues available to governments critically influence the total power available to labor and management in the public sector. Hence, if revenues were to turn down significantly, because of citizen and voter reactions against public employee unions or for other reasons, then public sector labor relations could face severe challenges.

Some analysts worry in particular that a future reduction in federal government revenue sharing combined with the ever-increasing amounts that 
state governments will have to contribute to cover the cost of Medicare obligations and public employee pension liabilities will create challenges that will extend indefinitely the revenue crisis that state and local governments faced after 2007. Countering this gloomy forecast is the fact that state and local government revenues have grown substantially, at least in nominal terms, over the last several years and many state and local government budgets have moved back into balance (Dadayan and Boyd 2013a). Total state tax collections, for example, were above their previous peak levels in real terms in most states by June 2013 (these peak levels were achieved in most states in 2007 or 2008) (Dadayan and Boyd 2013b: 1). At the same time, employment in state and local governments remains below 2007 levels. From December 2007 to December 2012, state government employment declined by $1.3 \%$ ( $-67,000$ jobs) and local government employment declined by $2.9 \%$ ( $-422,000$ jobs). This compares to a decline of $3.0 \%$ ( -3.5 million jobs) in private sector employment from 2007 to 2012 (Dadayan and Boyd 2013c). So, while the recent rebound in state and local government revenues bodes well for future public sector labor relations, the sluggish recovery in public sector employment and the possibility of future declines in revenue should worry supporters of public employee unionism.

3. In recent years, press coverage of the large pension liabilities and the potential underfunding within public employee pension funds has been substantial. Public concern over pension liabilities seems to be influenced by more general worries about the size of the national debt and the bankruptcies occurring in several countries (e.g., Greece) and in local U.S. governments (e.g., Detroit, Michigan, and Stockton and San Diego, California). Voter and legislator concerns about public pension are revealed in facts such as, "in the first six months of 2011, 25 states enacted significant revisions to their state retirement plans, with others still pending" (Bender and Heywood 2012: 140). As a result, the condition of public pensions could well be a key factor that influences public attitudes toward public employee unions and public sector collective bargaining when considering whether evidence links pension liabilities to public sector collective bargaining.

4. As discussed earlier in this essay, elementary and secondary education employment and related expenditures are a significant fraction of governmental activity, and local schools, like public pensions, receive substantial press attention given concerns parents have about the quality of the education received by their children. This concern shows up in the considerable focus on the role of teachers and the unions that often represent them in debates about the U.S. educational system. Correspondingly, the capability of unionized school districts and other unionized public sector jurisdictions to introduce cost savings and service quality improvements through negotiated changes is likely to limit the pressure to reduce the influence of teachers' unions. And whether teachers' unions are perceived as facilitators or resistors to school reform efforts is likely to extend beyond the education 
sector and influence public attitudes toward public sector labor relations in general.

Given the importance that public attitudes will exert on the course of public sector labor relations, future assessment and analysis of those attitudes is warranted. The public opinion polls cited earlier are helpful, but much more depth and breadth in the measurement of public attitudes toward public employee and union rights are sorely needed. On this issue, as with many of the issues identified in this article, little hard evidence is available and hence, the need is great for future research.

\section{References}

Anderson, Arvid. 1972. The structure of collective bargaining. In Sam Zagoria (Ed.), Public Workers and Public Unions, pp. 37-52. Englewood Cliffs, NJ: Prentice Hall.

Bender, Keith, and John Heywood. 2012. Trends in the relative compensation of state and local government employees. In D. J. B. Mitchell (Ed.), Public Jobs and Political Agendas, pp. 133-66. Labor and Employment Relations Association Series. Urbana-Champaign, IL: Labor and Employment Relations Association.

Bologna, Michael. 2012. Judge voids key provisions in Wisconsin law limiting public sector collective bargaining. Daily Labor Report, 180, September 22, pp. A1-2.

Burton, John, and Charles Krider. 1970. The role and consequences of strikes by public employees. Yale Law Journal, January, pp. 418-40.

Chelius, James, and James Dworkin. 1990. Reflections on the Transformation of Industrial Relations. Metuchen, NJ and London: ILMLR Press/Rutgers University and Scarecrow Press.

Dadayan, Lucy, and Donald J. Boyd. 2013a. States are not out of the woods despite strong revenue gains in the fourth quarter. State Revenue Report, April, issue 91. Albany, NY: Nelson Rockefeller Institute, University of Albany.

. 2013b. Strong gains in the first quarter; mounting uncertainty for the rest of 2013. State Revenue Report, issue 92. Albany, NY: Nelson Rockefeller Institute, University of Albany.

. 2013c. The depth and length of cuts in state-local government employment is unprecedented. Issue Brief, January. Albany, NY: Nelson Rockefeller Institute, University of Albany.

Dannin, Ellen. 2012. Cash-strapped governments: Privatization as a response to the crisis of the Great Recession. In D. J. B. Mitchell (Ed.), Public Jobs and Political Agendas, pp. 79-104. Labor and Employment Relations Association Series. Urbana-Champaign, IL: Labor and Employment Relations Association.

Dunlop, John T. 1988. Have the 1980's changed U.S. industrial relations? Monthly Labor Review 111(5) (May): 29-34.

. 1993. Industrial Relations Systems. Revised edition. Boston, MA: Harvard Business School Press, pp. 19-21.

Farber, Henry, and Harry Katz. 1979. Interest arbitration, outcomes and the incentive to bargain: The role of risk preferences. Industrial and Labor Relations Review 33(1): 55-63.

Fox, Alan. 1974. Beyond Contract. London: Faber and Faber.

Government Employee Relations Report. 1979. COPE charts impact of states' spending and tax limitations, 812 (May 28), 14-17.

Hefetz, Amir, and Mildred E. Warner. 2011. Contracting or public delivery? The importance of service, market, and management characteristics. Journal of Public Administration Research and Theory 22(2): 289-317.

Hefetz, Amir, Mildred E. Warner, and Eran Vigoda-Gadot. Forthcoming. Privatization and inter-municipal contracting: US local government experience, 1992-2007. Environment and Planning C: Government and Policy. 
Hicks, John. 1932. The Theory of Wages. London: MacMillan.

Hirsch, Barry T., and David A. Macpherson. 2013. Union membership and coverage database from Current Population Survey (CPS). Accessed at http://Unionstats.com.

Hurd, Richard W., and Tamara L. Lee. Forthcoming. Can U.S. Public Labor Relations Survive the Tea Party? Dispute Resolution in the Workplace: The Proceedings of the National Academy of Arbitrators 66.

Katz, Harry C. 1979. Municipal pay determination: The case of San Francisco. Industrial Relations 18 (Winter): 44-59. . 1985. Shifting Gears. Cambridge, MA: MIT Press.

Katz, Harry C., and Owen Darbishire. 2000. Converging Divergences: Worldwide Changes in Employment Systems. Ithaca, NY: Cornell University Press/ILR Press.

Katz, Harry C., and Thomas A. Kochan. 2004. An Introduction to Collective Bargaining and Industrial Relations. 3rd edition. New York: McGraw-Hill/Irwin.

Katz, Harry C., Thomas A. Kochan, and Alexander J. S. Colvin. 2008. An Introduction to Collective Bargaining and Industrial Relations. 4th edition. New York: McGraw-Hill/Irwin.

Kerr, Clark, John T. Dunlop, Frederick Harbison, and Charles A. Myers. 1960. Industrialism and Industrial Man. Cambridge, MA: Harvard University Press.

Kochan, Thomas A. 1974. A theory of multi-lateral bargaining in city governments. Industrial and Labor Relations Review 4 (July): 526.

Kochan, Thomas A., Harry C. Katz, and Robert B. McKersie. 1986. The Transformation of American Industrial Relations. New York: Basic Books.

Lewin, David, and Mary McCormick. 1981. Coalition bargaining in municipal government: The New York City experience. Industrial and Labor Relations Review 34(2): 175-90.

Lewin, David, Jeffrey H. Keefe, and Thomas A. Kochan. 2012. The new great debate about unionism and collective bargaining in U.S. state and local governments. ILR Review 65(4): 747-75.

Linn, Amy. 2012. Idaho voters say no to GOP-backed school overhaul, anti-union measures. Daily Labor Report 218, November 12, A-5.

Loeb, Susanna, Jon Valant, and Matt Kasman. 2011. Increasing choice in the market for schools: Recent reforms and their effects on student achievement. National Tax Journal 64(1): 141-64.

Marshall, Alfred. 1920. Principles of Economics. 8th edition. New York: MacMillan.

McClennan, Kenneth, and Michael H. Moskow. 1968. Multilateral bargaining in the public sector, in Proceedings of the 21st Annual Meeting, Industrial Relations Research Association (IRRA), pp. 34-41. Madison, WI: IRRA.

Mitchell, Daniel J. B. 2012. California's public sector adapts to the Great Recession. In D. J. B. Mitchell (Ed.), Public Jobs and Political Agendas. Labor and Employment Relations Association Series. Urbana-Champaign, IL: Labor and Employment Relations Association.

New York Times and CBS News Poll. 2011. February 24-27, accessed at http://www.nytimes .com/interactive/2011/02/28/us/28union-poll-results.html.

Ravitch, Diane. 2010. The myth of charter schools. New York Review of Books. November 11, p. 22.

Rubinstein, Saul, and John McCarthy. 2012. Public school reform through union-management collaboration. In David Lewin and Paul J. Gollan (Eds.), Advances in Industrial and Labor Relations, vol. 19. Bingley, UK: Emerald Group.

Sclar, Elliot D. 2001. You Don't Always Get What You Pay For: The Economics of Privatization. Ithaca, NY: Cornell University Press.

U.S. Department of Labor. 1996. Working together for public service. Report of the U.S. Secretary of Labor's Task Force on Excellence in State and Local Government through Labor-Management Cooperation, May. Washington, DC.

Weitzman, Joan P. 1979. The effect of economic restraints on public sector collective bargaining: The lessons from New York City. In Government Labor Relations: Trends and Information for the Future, pp. 334-46. Oakpark, IL: Moore.

Wellington, Harry H., and Ralph K. Winter Jr. 1969. The limits of collective bargaining in public employment. Yale Law Journal, June, pp. 1107-27.

1. 1971. The Unions and the Cities. Washington, DC: The Brookings Institution. 
Copyright of Industrial \& Labor Relations Review is the property of Cornell University and its content may not be copied or emailed to multiple sites or posted to a listserv without the copyright holder's express written permission. However, users may print, download, or email articles for individual use. 